\title{
Effect of eCG applied to dairy cows in the postpartum period on ovarian activity and reproductive performance ${ }^{1)}$
}

\author{
KUDRET YENILMEZ, NURULLAH ÖZDEMIR* \\ Department of Obstetric and Gynecology; *Department of Farmacology and Toxicology, \\ Veterinary Faculty, Tekirdağ Namık Kemal University, Tekirdağ, Turkey
}

\section{Yenilmez K., Özdemir N. \\ Effect of eCG applied to dairy cows in the postpartum period on ovarian activity and reproductive performance}

Summary

The aim of this study was to determine the effect of equine chorionic gonadotropin (eCG) applied in postpartum ( $\mathrm{pp}$ ) period on ovarian follicle development, serum estradiol concentration, serum progesterone concentration, the calving-to-first oestrus (calving-to-first insemination) interval, and conception at first insemination. The material of this study consisted of 20 cows on day $14 \mathrm{pp}$. Cows included in this study were randomly divided into two groups. Cows in the first group, were treated with eCG (500 IU Folligon; Intervet, Holland) for 14 days. No treatment was applied to the second group, and it was left as a control group, Ovarian follicle diameters were measured by ultrasonographic examination on days 14, 16, 18, 20 and $22 \mathrm{pp}$ in all animals included in the study. Serum estradiol and progesterone were from blood samples taken on the same days. All animals included in the study were followed up until the first observable oestrus was detected, and they were inseminated 12 hours after the appearance of oestrus symptoms. A pregnancy examination was performed on the 45th day after insemination. In cows administered with eCG during postpartum period, an increase in ovarian follicle diameters compared to untreated cows and a decrease in the calving-to-first oestrus interval were determined. In contrast, serum estradiol and progesterone hormone levels did not differ between the two groups. Pregnancy rate in the experimental group was higher than that in the control group, but there was no statistical difference between them. As a result, it was concluded that eCG applied to dairy cows on day 14 pp did not affect serum estradiol and progesterone levels, but it affected the ovarian follicle diameter and the calving-to-first oestrus interval positively.

Keywords: dairy cows, postpartum, eCG, ovarian activity, reproductive performance

It is necessary to obtain a calf from each cow a year to perform dairy cow breeding economically. It is reported that, in order to achieve this goal, the duration of postpartum anoestrus should not exceed 60 days, the duration of the calving to conception interval should optimally be 90 days and should not exceed 100 days $(5,45,78)$.

Since the lactation cycle in dairy cows starts and is renewed with calving, reproductive efficiency is of great importance (31). In recent years, there has been a decrease in the fertility of cows despite an increase in the milk yields of lactating cows (23). This decrease in fertility has been associated with improvement in

The Scientific Research Projects Coordination Unit of Tekirdağ Namık Kemal University supported the present study (Project Number: NKUBAP.10. GA.17.088). genetic progress, nutrition and management conditions (24).

The period following the birth, during which a number of events occur, such as the involution of the uterus, regeneration of the endometrium, elimination of bacterial contamination in the uterus, and the recurrence of cyclic activity in the ovaries, while the female genital tract prepares itself for a new pregnancy, is called the postpartum period. The fact that this period lasts longer than normal negatively affects the reproductive performance of the cow (28). Approximately 6 weeks after birth, the genital tract is almost ready for a new pregnancy. This normal process, which is expected after birth, does not progress in this way in more than half of farm animals, and it has been reported that ovarian activities do not start until day $60 \mathrm{pp}$ in $6-59 \%$ 
of cows $(9,37,44)$. It has recently been reported that the interval from calving to the first ovulation has extended and that postpartum anoestrus is observed in $11-38 \%$ of cows (25). Postpartum anoestrus extends intervals from calving to the first ovulation and from calving to conception and reduces reproductive efficiency $(18,46)$. The first follicular wave after calving is formed around days 5-7 pp, and the follicle reaches the maximum size $(>10 \mathrm{~mm})$ on day $10 \mathrm{pp}(6,39)$. It is reported that the first dominant follicle is ovulated at a rate of $46 \%$ and cysted at a rate of $23 \%$. The ovulation of the first dominant follicle on day $31 \mathrm{pp}$ reduces the $\mathrm{pp}$ anoestrus (5).

Equine chorionic gonadotropin $(\mathrm{eCG})$ is a hormone produced by trophoblast cells in endometrial vessels of pregnant mares. It plays an important role in maintaining early pregnancy in mares (21). Although eCG is a luteinizing hormone $(\mathrm{LH})$ in equidae, it acts as both follicular stimulating hormone (FSH) and $\mathrm{LH}$ in other animal species $(12,26)$. The follicular development and ovulation in cows can be stimulated by its parenteral administration $(17,41)$. It has been reported that eCG administered on day $6 \mathrm{pp}$ is effective in early stimulation of ovarian activity and increases fertility by decreasing the calving-to-conception interval (32, 45 ). It has been reported that eCG administered on day $14 \mathrm{pp}$ increases the follicular development in the ovary ipsilateral cornu uteri, in which a previous pregnancy has been formed, and the estradiol concentration in blood (41).

This study was carried out to investigate the effect of eCG administered on day $14 \mathrm{pp}$ on the development of ovarian follicles, and on serum estradiol and progesterone concentrations, as well as on the calvingto-first oestrus (calving-to-first insemination) interval and conception after the first insemination.

\section{Material and methods}

Twenty multiparous Holstein cows at the age of four years on day $14 \mathrm{pp}$ were used as material. For the study, ethics committee approval was obtained from Namık Kemal University Animal Experiments Local Ethics Committee $(2016 / 10)$. The animals were obtained from a private enterprise in Silivri district of Istanbul province. The animals that had recently given birth and had not gone through puerperal disease (dystocia, retained placenta, endometritis, laminitis, mastitis, displaced abomasum) were used in the study. The milk yield of these animals was close to each other, and they were fed with the same ration in the same free-stall barn. The cows included in the study were randomly divided into two groups. The cows in the first group were administered with eCG (500 IU Folligon; Intervet, Holland) on day 14 pp. No treatment was applied to the second group, and it was left as a control group. The ultrasonographic examination of the ovary was performed via the transrectal route using a real-time ultrasonography device with a $5-\mathrm{MHz}$ linear array probe (Hasvet WED-3100V) before the hormone administration (day 0), and on days 2, 4, 6 and 8 after the administration. The largest diameters of the follicles detected in both ovaries measured in the vertical and horizontal directions were evaluated and recorded. Blood samples were drawn from the tail vein into $10 \mathrm{ml}$ anticoagulant-free vacutainer tubes on the same days. Serum was obtained by centrifuging blood samples at $4000 \mathrm{rpm}$ for 20 minutes. Serums were stored at $-20^{\circ} \mathrm{C}$ in Eppendorf tubes until estradiol and progesterone analyses were performed. Estradiol and progesterone values were determined by the ACS technique in the Automated Chemiluminescence System (Siemens Immulite 2000) using ACS analysis kits in a special laboratory. All animals included in the study were followed up until the first observable oestrus was detected. Oestrus detection was performed three times a day $(5: 00$, 14:00, 20:00) by observing the animals for 30 minutes each time. The cows with signs of edema and hyperemia in the vulva, mucus discharge and allowing another animal to jump on them (standing reflex) were accepted to be in oestrus. All animals included in the study were inseminated by the same technician and using the same bull sperm 12 hours after oestrus symptoms were observed. The calving examination was performed by ultrasonography on day 45 after insemination.

Statistical analyses. SPSS 22 package program was used for the preparation of statistical data. The results were presented as mean \pm standard deviation. Normality was tested by the Shapiro-Wilk test. The ANOVA test was used in those normally distributed, and the Mann-Whitney U test was used in those not normally distributed. The ANOVA test was used to compare the differences between the groups in terms of estradiol levels and the calving-to-first oestrus interval. The paired t-test was applied to investigate the effect of eCG administered to the experimental group on estradiol levels over time. The Mann-Whitney U test was used to compare the differences between the groups in terms of progesterone values and follicle diameter. The chi-square test was used to compare pregnancy rates. $\mathrm{P}<0.05$ was considered to be statistically significant.

\section{Results and discussion}

In the study, the control group included 10 cows, and the eCG-treated group included 10 cows. Although serum estradiol concentration increased on days 2,4 and 6 after eCG administration in the experimental group such an increase was not observed in the control group, and there was no significant difference in terms of estradiol concentrations between the two groups. The paired t-test performed in the experimental group demonstrated that eCG administration in the experimental group did not lead to a significant increase in estradiol levels over time $(\mathrm{P}<0.05$, Tab. 1$)$.

No significant difference was found between the control and experimental groups in terms of serum progesterone measurements performed on the first (day 0) and last (day 8) days on which blood samples were collected $(\mathrm{P}<0.05$, Tab. 2).

There was no difference between the control (10.90 $\pm 1.20)$ and experimental groups $(10.50 \pm 1.51)$ in terms 
Tab. 1. Estradiol levels in the control and experimental groups according to working days $(\overline{\mathrm{x}} \pm \mathrm{Sd})$

\begin{tabular}{|c|c|c|}
\hline Day & Control & Experimental \\
\hline 0 & $48.15 \pm 13.92^{\mathrm{a}}$ & $45.72 \pm 12.35^{\mathrm{a}}$ \\
2 & $47.38 \pm 14.63^{\mathrm{a}}$ & $49.86 \pm 12.40^{\mathrm{a}}$ \\
4 & $48.19 \pm 11.90^{\mathrm{a}}$ & $48.33 \pm 16.37^{\mathrm{a}}$ \\
6 & $43.46 \pm 10.63^{\mathrm{a}}$ & $50.39 \pm 24.20^{\mathrm{a}}$ \\
8 & $43.00 \pm 9.92^{\mathrm{a}}$ & $46.34 \pm 21.22^{\mathrm{a}}$ \\
\hline
\end{tabular}

Tab. 2. Serum progesterone values in the control and experimental groups according to working days $(\overline{\mathbf{x}} \pm \mathbf{S d})$

\begin{tabular}{|c|c|c|c|}
\hline \multicolumn{4}{|c|}{ Progesteron $(\mathrm{ng} / \mathrm{mL})$} \\
Day & Control & Experimental & $\begin{array}{c}\text { p-value } \\
\text { Mann-Whitney }\end{array}$ \\
\hline 0 & $0.27 \pm 0.21^{\mathrm{a}}$ & $0.35 \pm 0.45^{\mathrm{a}}$ & 0.353 \\
8 & $0.88 \pm 0.93^{\mathrm{a}}$ & $0.78 \pm 0.81^{\mathrm{a}}$ & 0.853 \\
\hline
\end{tabular}

Tab. 3. Ovarian follicle diameters $(\mathrm{mm})$ in the control and experimental groups according to working days $(\overline{\mathrm{x}} \pm \mathbf{S d})$

\begin{tabular}{|c|c|c|}
\hline Day & Control & Experimental \\
\hline 0 & $10.90 \pm 1.20^{\mathrm{a}}$ & $10.50 \pm 1.51^{\mathrm{a}}$ \\
\hline 2 & $10.80 \pm 1.48^{\mathrm{a}}$ & $12.30 \pm 1.25^{\mathrm{b}}$ \\
\hline 4 & $10.70 \pm 1.06^{\mathrm{a}}$ & $11.80 \pm 2.57^{\mathrm{a}}$ \\
\hline 6 & $10.10 \pm 0.99^{\mathrm{a}}$ & $12.00 \pm 3.53^{\mathrm{a}}$ \\
8 & $10.20 \pm 0.92^{\mathrm{a}}$ & $11.20 \pm 3.01^{\mathrm{a}}$ \\
\hline
\end{tabular}

Explanation: ${ }^{\mathrm{a}, \mathrm{b}}-$ significant at $\mathrm{p} \leq 0.05$

Tab. 4. Calving-to-first oestrus (calving-first insemination) durations in the control and experimental groups $(\bar{x} \pm \mathrm{Sd})$

\begin{tabular}{|c|c|c|c|}
\hline \multirow{2}{*}{ Control } & \multirow{2}{*}{ Experimental } & \multicolumn{2}{|c|}{$\mathrm{p}$-value } \\
& & ANOVA & Mann-Whitney \\
\hline $73.6 \pm 18.12^{\mathrm{a}}$ & $\mathbf{5 4 . 5 0} \pm 19.55^{\mathrm{b}}$ & $\mathbf{0 . 0 3 6}$ & $\mathbf{0 . 0 4 9}$ \\
\hline
\end{tabular}

Explanation: as in Tab. 3

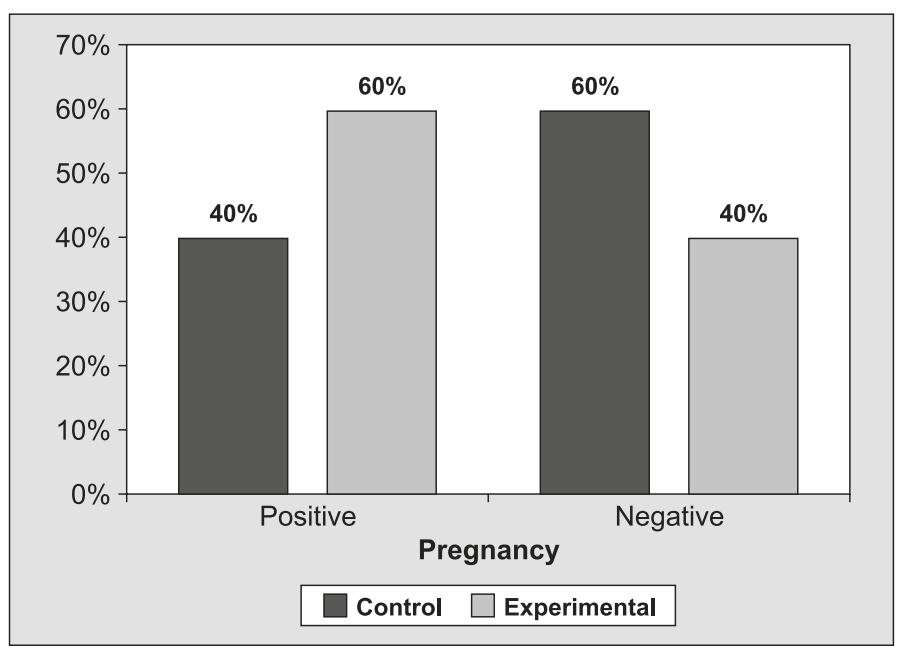

Fig. 1. Pregnancy rates obtained in the control and experimental groups of the ovarian follicle diameters on day 0 of the study. On day 2 of the study, the follicular diameter in the experimental group $(12.30 \pm 1.25)$ was higher compared to that in the control group $(10.80 \pm 1.48)(\mathrm{P}<0.05)$. Although the follicular diameters on days 4,6 and 8 of the study were higher in the experimental group compared to those in the control group, the difference between them was not statistically significant (Tab. 3).

All animals included in the study were followed up until the first observable oestrus was detected. The calving-to-first observable oestrus interval (54.50 $\pm 19.55)$ was found to be significantly $(\mathrm{P}<0.05)$ shorter in the experimental group $(54.50 \pm 19.55)$ compared to the control group (73.6 \pm 18.12$)$ (Tab. 4). Since all animals were artificially inseminated on the first day when oestrus was detected, the calvingto-first oestrus interval is also the calving-to- first insemination interval. Although the pregnancy rate at the first insemination was higher in the experimental group (60\%) compared to the control group (40\%), there was no statistical difference between them $(\mathrm{P}<0.05$, Fig. 1).

The fact that there was no significant difference between the experimental and control groups in terms of all parameters examined on day 0 when the study was initiated indicates that the distribution of the subjects to the control and experimental groups was performed well and that the obtained results did not originate from the selection of subjects.

The main aim of this study was to investigate the effect of eCG administered on day $14 \mathrm{pp}$ on reproductive performance of multiparous Holstein cows. It has been reported that ovarian activity can be initiated early with postpartum eCG administration in Holstein dairy cows, early ovulation can be stimulated by increasing follicle development and folliculogenesis in ovaries, and the calving-to-conception interval can be shortened $(32,41,45)$. It is reported that the fertility of cows with early ovarian activity is high $(15,37)$. However, the extension of the postpartum anoestrus period and the delay of spontaneous oestrus decrease fertility $(36,42)$.

While the calving-to-first insemination interval in dairy cows, in which the cyclic activity of the ovary started on days 21 and $49 \mathrm{pp}$, was reported to be 71 to 76 days, respectively, this period extended up to 96 days in cows without cyclic activity within the first 49 days $p p$ (15). This duration is reported to decrease with the administration of eCG and PGF $2 \alpha$ in the postpartum period $(11,14,45)$. However, there are also researchers reporting that $600 \mathrm{IU}$ of eCG administered between days 9-15 pp does not affect intervals from calving to first oestrus and from calving to conception (13). In our study, it was determined that eCG administered on day 14 pp in dairy cows (54.50 \pm 19.55 ) reduced the calving-to-first oestrus (calvingto-first insemination) interval compared to the control 
group (73.6 \pm 18.12$)$. Vojgani et al. (45) reported that this interval was $74.4 \pm 1.76$ days in the eCG group and $84.2+2.79$ days in the control group. Similarly, Darwash et al. (11) and Galvao et al. (14) also reported that they reduced this interval with $\mathrm{PGF}_{2 \alpha}$ administration on days 12-14 pp and on day $21 \mathrm{pp}$, respectively. Sakaguchi (34) also reported that this interval was 42.8 \pm 2.3 and $79.6 \pm 5.1$ days depending on the differences in follicular dynamics. Our values were found to be lower than the values found by Vojgani et al. (45) and in the range of values reported by Sakaguchi (34). The fact that eCG administered on day $14 \mathrm{pp}$ shortened the calving-to-first oestrus, calving-to-first insemination interval may be attributed to the early onset of ovarian activity by eCG.

It is reported that the first follicle development wave starts within days 7-10 pp along with the increase in follicular stimulating hormone levels between days $3-5 \mathrm{pp}$ in cows (10); the first dominant follicle is ovulated at a rate of $30-80 \%(35,38)$; and the first ovulation occurs without oestral behaviors $(2,19)$. Bastan et al. (4) reported that the ovarian follicle diameter was $10.8 \pm 3.5 \mathrm{~mm}$ in cows without problems on day $14 \mathrm{pp}$. There was no difference between the control group $(10.90 \pm 1.20)$ and the experimental group (10.50 $\pm 1.51)$ in terms of the ovarian follicle diameters on day 0 (pp day 14) of the study, which is compatible with the values obtained by Bastan et al. (4). The fact that the follicle diameter of the eCG-treated group $(12.30 \pm 1.25)$ on the $2^{\text {nd }}$ day of the study was higher compared to the follicle diameter of the control group $(10.80 \pm 1.48)$ indicates that eCG supported the follicular development. Similarly, Sheldon and Dobson (41) reported that 250 and 750 IU eCG they administered on day $14 \mathrm{pp}$ increased the follicular growth. Rostami et al. (32) reported that eCG administered on day $6 \mathrm{pp}$ helped the early onset of ovarian activity and stimulated the follicular growth and ovulation. eCG, which is included in fixed-time artificial insemination protocols, has also been reported to increase the dominant follicle diameter $(7,30)$. However, unlike other researchers and us, there are also researchers reporting that $500 \mathrm{IU}$ eCG administered on day $8 \mathrm{pp}$ does not have an enhancing effect on follicular growth (8). The fact that eCG supports follicular development is thought to occur due to its FSH effect in cows.

Serum progesterone and estradiol concentrations provide valuable information on the determination of the reproductive performance of dairy cows. They can also be used as a measure for determining the causes of poor reproductive performance (43). Savio et al. (39) measured plasma estradiol concentration to be 5-110 $\mathrm{pg} / \mathrm{ml}$ in Holstein cows they monitored starting from day $5 \mathrm{pp}$ until the first ovulation and they reported high values in dominant and cystic follicles. Skenandore et al. (43) measured estradiol concentration to be
$15-65 \mathrm{pg} / \mathrm{ml}$ in the cow serums they collected at various stages of the estrous cycle. The estradiol values measured in our study varied between $20.0-99.8 \mathrm{pg} / \mathrm{ml}$. In our study, an increase was determined in estradiol concentration along with eCG administration. However, this increase was not statistically significant. The reason for this is thought to be a small number of subjects. Sheldon and Dobson (41) reported that 250 and $750 \mathrm{IU}$ eCG administered on day $14 \mathrm{pp}$ increased plasma estradiol concentration. Similarly, Honnens et al. (16) reported that eCG added to estrus synchronization programs on day 10 in Holstein cows increased plasma estrogen hormone levels on day 13.

With in vitro experiments, Kuran et al. (20) and Liu et al. (22) demonstrated that eCG increased progesterone production. The fact that eCG treatment increases progesterone production and the corpus luteum diameter in cows has been confirmed by in vivo experiments $(3,33)$. Honnens et al. (16) reported that eCG added to estrus synchronization programs on day 10 in Holstein cows increased plasma progesterone levels. Rostami et al. (32) reported that eCG administered on day $6 \mathrm{pp}$ had a stimulating effect on the development of corpus luteum in the first cycle and that this administration also caused an increase in the serum progesterone amount. We determined that eCG administered on day $14 \mathrm{pp}$ did not cause a significant increase in serum progesterone levels on day $22 \mathrm{pp}$ and a similar increase was observed in the control group. Patron-Collantes et al. (29) reported that 500 IU eCG administered between days 11-17 pp in high-yielding dairy cows under heat stress did not increase pregnancy rates at first insemination $(34.9 \%$ in the eCG group, $31.8 \%$ in the control group). Freick et al. (13) reported that a single dose (600 IU) of eCG administered between days 9-15 pp did not affect the calving-to-first oestrus, calving-tofirst insemination interval and the pregnancy rate at first insemination. Vojgani et al. (45) reported that $500 \mathrm{IU}$ of eCG administered on day 6 pp positively affected the reproductive performance by shortening the calving-to-first oestrus, calving-to-first insemination interval but did not increase pregnancy rates at first insemination. In our study, it was determined that eCG administered on day 14 pp significantly shortened the calving-to-first oestrus, calving-to-first insemination interval and increased the pregnancy rate at first insemination although not significantly. We believe that these effects of eCG administered in the postpartum period can be attributed to the early onset of ovarian activity by eCG.

As a result, it was concluded that $500 \mathrm{IU}$ of eCG administered on day $14 \mathrm{pp}$ could be used to initiate follicular development in the ovary early and that this administration would make positive contributions to fertility and reproductive performance in Holstein dairy cows. 


\section{References}

1. Alaçam E.: İneklerde İnfertilite Sorunu, [in:] Alaçam E. (ed.): Evcil Hayvanlarda Doğum ve İnfertilite. $5^{\text {th }}$ Ed., (Alaçam, E. Ed.) Ankara, Medisan, Turkey 2005, p. 267-290 (in Turkish).

2. Alan M., Taşal I., Çetin Y., Saban E., Uyar A.: Prediction of Postpartum Ovarian Activity by Serum Progesteron Levels and Clinical Observations in Cows. Y.Y.U. Vet. Fak. Derg. 2000, 11, 60-64.

3. Baruselli P., Marques M., Hoffmann E., Costa Neto W. P., Grandinetti R., $B o G$.: Increased pregnancy rates in embryo recipients treated with CIDR-B devices. Theriogenology 2001, 55, 355 .

4.Baştan A., Alaçam E., Güven B., Fındık M., Erünal M.: The investigation of ovarian follicular dynamics by evaluation of certain hormone levels and ultrasonography in the puerperium of Holstein cows. Ankara Univ. Vet. Fak. Derg. 1998, 45, 73-81.

5. Beam S. W., Butler W. R.: Effects of energy balance on follicular development and first ovulation in postpartum dairy cows. J. Reprod. Fert. Supplement 1999, 54, 411-424.

6. Beam S. W., Butler W. R.: Energy balance, metabolic hormones, and early postpartum follicular development in dairy cows fed prilled lipid. J. Dairy Sci. 1998, 81, 121-131

7. Bo G. A., De La Mata J. J., Baruselli P. S., Menchaca A.: Alternative programs for synchronizing and resynchronizing ovulation in beef cattle. Theriogenology 2016, 86, 388-396.

8. Canadas E. R., Lonergan P., Butler S. T.: Effect of equine chorionic gonadotropin administration on day 8 post-partum on ovarian follicular development, uterine health and uterine involution in lactating dairy cows. Theriogenology 2019, 123, 54-61.

9. Cerri R. L. A., Santos J. E. P., Juchem S. O., Galvao K. N., Chebel R. C.: Timed artificial insemination with estradiol cypionate or insemination at estrus in high-producing dairy cows. J. Dairy Sci. 2001, 87, 3704-3715.

10. Crowe M. A.: Resumption of ovarian cyclicity in post-partum beef and dairy cows. Reprod. Dom. Anim. 2008, 43, 20-28.

11. Darwash A. O., Lamming G. E., Royal M. D.: A protocol for initiating oestrus and ovulation early post partum in dairy cows. Anim. Sci. 2001, 72, 539-546.

12.De Rensis F., Lopez-Gatius F.: Use of equine chorionic gonadotropin to control reproduction of the dairy cow: a review. Reprod. Dom. Anim. 2014, 49, 177-182.

13. Freick M., Passarge O., Weber J.: Lack of effects of an equine chorionic gonadotropin (eCG) administration between days 9 and 15 postpartum on reproductive performance in a Holstein dairy herd. Reprod. Dom. Anim. 2017, 52, 429-436.

14. Galvao K. N., Frajblat M., Brittin S. B., Butler W. R., Guard C. L., Gilbert R. $O$.: Effect of prostaglandin F2 $\alpha$ on subclinical endometritis and fertility in dairy cows. J. Dairy Sci. 2009, 92, 4906-4913.

15. Galvao K. N., Frajblat M., Butler W. R., Brittin S. B., Guard C. L., Gilbert $R$. $O$.: Effect of early postpartum ovulation on fertility in dairy cows. Reprod. Dom. Anim. 2010, 45, 207-211.

16. Honnens A., Niemman H., Herzog K., Paul V., Meyer H. H. D., Bollwein H. Relationships between ovarian blood flow and ovarian response to eCGtreatment of dairy cows. Anim. Reprod. Sci. 2009, 113, 1-10.

17. Hosseini A., Niasari-Naslaji A., Vojgani M., Gharagozloo F.: Effect of time of eCG administration on the fate of ovarian follicle in Holstein heifers. Iran. J. Vet. Res. 2018, 19, 15-21.

18. Kawashima C., Kaneko E., Montoya C. A., Matsui M., Yamagishi N., Matsunaga N., Miyamoto A.: Relationship between the first ovulation within three weeks postpartum and subsequent ovarian cycles and fertility in high producing dairy cows. J. Reprod. Develop. 2006, 52, 479-486.

19. Kyle S. D., Callahan C. J., Allrich R. D.: Effect of progesterone on the expression of estrus at the first postpartum ovulation in dairy cattle. J. Dairy Sci. 1992, 75, 1456-1460.

20. Kuran M., Broadbent P. J., Hutchinson J. M.: Bovine granulosa cell culture for assessment of potency and specificity of antibodies to pregnant mares' serum gonadotrophin. Europ. J. Endocrinol. 1996, 134, 497-500.

21. Legardinier S., Cahoreau C., Klett D., Combarnaus Y.: Involvement of equine chorionic gonadotropin (eCG) carbohydrate side chains in its bioactivity; lessons from recombinant hormone expressed in insect cells. Reprod. Nut. Develop. 2005, 45, 255-259.

22. Liu Z. H., Yue K. Z., Ma S. F., Sun X. S., Tan J. H.: Effects of pregnant mare serum gonadotropin (eCG) on follicle development and granulosa-cell apoptosis in the pig. Theriogenology 2003, 59, 775-785.

23. Lopez-Gatius F: Factors of a noninfectious nature affecting fertility after artificial insemination in lactating dairy cows. A review. Theriogenology 2012, 77, 1029-1041

24. Lucy M. C.: Reproductive loss in high-producing dairy cattle: where will it end? J. Dairy Sci. 2001, 84, 1277-1293.
25. Moreira F., Orlandi C., Risco C. A., Mattos R., Lopes F., Thatcher W. W. Effects of presynchronization and bovine somatotropin on pregnancy rates to a timed artificial insemination protocol in lactating dairy cows. J. Dairy Sci. 2001, 84, 1646-1659.

26. Murphy B. D.: Equine chorionic gonadotropin: an enigmatic but essential tool. Anim. Reprod. 2012, 9, 223-230.

27. Mwaanga E. S., Janowski T.: Anoestrus in dairy cows: causes, prevalence and clinical forms. Reprod. Dom. Anim. 2000, 35, 193-200.

28. Ocal H., Kalkan C.: Puerperal Dönem Fizyolojisi, [in:] Semacan A., Kaymaz M., Fındık M., Rişvanlı A., Köker A. (eds.): Çiftlik Hayvanlarında Doğum ve Jinekoloji. $2^{\text {nd }}$ ed. Medipres, Malatya, Turkey 2015, p. 275-303.

29. Patron-Collantes R., Lopez-Helguera I., Pesantez-Pacheco J. L., Sebastian F., Fernandez M., Fargas O., Astiz S.: Early postpartum administration of equine chorionic gonadotropin to dairy cows calved during the hot season: Effects on fertility after first artificial insemination. Theriogenology 2017, 92, 83-89.

30. Prata A. B., Drum J. N., Melo L. F., Araujo E. R., Sartori R.: Effect of different chorionic gonadotropins on final growth of the dominant follicle in Bos indicus cows. Theriogenology 2018, 111, 52-55.

31. Pulley S. L., Wallace L. D., Mellion Jr H. I., Stevenson J. S.: Ovarian characteristics, serum concentrations of progesterone and estradiol, and fertility in lactating dairy cows in response to equine chorionic gonadotropin. Theriogenology 2013, 79, 127-134.

32. Rostami B., Niasari-Naslaji A., Vojgani M., Nikjou D., Amanlou H., Gerami A. Effect of eCG on early resumption of ovarian activity in postpartum dairy cows. Anim. Reprod. Sci. 2011, 128, 100-106.

33. Sa Filho M. F., Torres-Junior J. R. S., Penteado L., Gimenes L. U., Ferreira R. M., Ayres H., Baruselli P. S.: Equine chorionic gonadotropin improves the efficacy of a progestin-based fixed-time artificial insemination protocol in Nelore (Bos indicus) heifers. Anim. Reprod. Sci. 2010, 118, 182-187.

34. Sakaguchi M.: Reproductive Potential of Japanese High-producing Dairy Cattle. Jap. Agric. Res. Quar. 2012, 46, 311-319.

35. Sakaguchi M., Sasamoto Y., Suzuki T., Takahashi Y., Yamada Y.: Postpartum ovarian follicular dynamics and estrous activity in lactating dairy cows. J. Dairy Sci. 2004, 87, 2114-2121.

36. Santos J. E. P., Bisinotto R. S., Ribeiro E. S.: Mechanisms underlying reduced fertility in anovular dairy cows. Theriogenology 2016, 86, 254-262.

37. Santos J. E. P., Rutigliano H. M., Sa Filho M. F.: Risk factors for resumption of postpartum estrous cycles and embryonic survival in lactating dairy cows. Anim. Reprod. Sci. 2009, 110, 207-221.

38. Sartori R., Haugian J. M., Shaver R. D., Rosa G. J. M., Wiltbank M. C.: Comparison of ovarian function and circulating steroids in estrous cycles of Holstein heifers and lactating cows. J. Dairy Sci. 2004, 87, 905-920.

39. Savio J. D., Boland M. P., Hynes N., Roche J. F.: Resumption of follicular activity in the early post-partum period of dairy cows. J. Reprod. Fertil. 1990 $88,569-579$

40. Sheldon I. M., Cronin J., Goetze L., Donofrio G., Schuberteh H. J.: Defining postpartum uterine disease and the mechanisms of infection and immunity in the female reproductive tract in cattle. Biol. Reprod. 2009, 81, 1025-1032.

41. Sheldon I. M., Dobson H.: Effect of administration of eCG to postpartum cows on folliculogenesis in the ovary ipsilateral to the previously gravid uterine horn and uterine involution. J. Reprod. Fertil. 2000, 119, 157-163.

42. Shrestha H. K., Nakao T., Suzuki T., Higakhi T., Akita M.: Effects of abnorma ovarian cycles during pre-service period postpartum on subsequent reproductive performance of high-producing Holstein cows. Theriogenology 2004, 61, 1559-1571.

43. Skenandore C. S., Pineda A., Bahr J. M., Newell-Fugate A. E., Cardoso F. C. Evaluation of a commercially available radioimmunoassay and enzyme immunoassay for the analysis of progesterone and estradiol and the comparison of two extraction efficiency methods. Dom. Animal Endocrinol. 2017, 60, 61-66.

44. Stevenson J. S., Pursley J. R., Garverick H. A., Fricke P. M., Kesler D. J., Ottobre J. S., Wiltbank M. C.: Treatment of Cycling and Noncycling Lactating Dairy Cows with Progesterone During Ovsynch1. J. Dairy Sci. 2006, 89, 2567-2578.

45. Vojgani M., Akbarinejad V., Niasari-Naslaji A.: Administration of eCG on Day 6 postpartum could enhance reproductive performance of Holstein dairy cows. Anim. Reprod. Sci. 2013, 138, 159-162.

46. Walsh R. B., Kelton D. F., Duffield T. F., Leslie K. E., Walton J. S., Leblanc $S$. J.: Prevalence and risk factors for postpartum anovulatory condition in dairy cows. J. Dairy Sci. 2007, 90, 315-324.

Corresponding author: Dr. Üyesi Kudret Yenilmez, Tekirdağ Namık Kemal University, Veterinary Faculty, Obstetric and Gynecology Department, Tekirdağ, Turkey; e-mail: kyenilmez@nku.edu.tr 